\title{
Technogenic Deposits in Russia: Precious Metals Stocks and Prospects of Their Recovery
}

\author{
Anna Boduen ${ }^{1}$, George Petrov ${ }^{1}$, Maria Ttoitskaya ${ }^{1} \&$ Svetlana Fokina $^{1}$ \\ ${ }^{1}$ Mining University, Saint-Petersburg, Russia \\ Correspondence: Anna Boduen, Mining University, Saint-Petersburg, Russia. Tel: 8-812-328-8459. E-mail: \\ bodyen-anna@mail.ru
}

Received: March 10, 2013 Accepted: April 10, 2013 Online Published: November 11, 2013

doi:10.5539/jmsr.v3n1p21 URL: http://dx.doi.org/10.5539/jmsr.v3n1p21

\begin{abstract}
Russia possesses a high potential for resource growth and platinoid reserves, and technogenic waste of complex ore processing can become a considerable part of the process in the near future. It is practical to take into account impounded mill tailings of sulphide copper-nickel ores, old pyrrhotine concentrates (OPC), impounded magnetite concentrates and slag-dust dumps of the mining and metallurgical company "Norilsk Nickel" (MMC NN), as well as technogenic platinum-metal chromite placer deposits of Ural and Aldan.

In spite of big volumes, secondary resources are characterized by unstable content of PGM and nonferrous metals. The forms of finding platinum group metals are so that raw material is difficult to be processed by conventional technological schemes. At that production cost of PGM extraction from technogenic deposits sometimes can be lower than when concentration of initial ores and sands, whereas the cost intensive operations connected with mining, crushing, grinding and classification are excluded from the processing chain.
\end{abstract}

Keywords: technogenic deposit, platinum metals, pyrrhotine concentrate, slag-dust, mill tailings

\section{Introduction}

The extension and restructuring of the mineral and raw material resources base of platinum-group metals is an important aspect of development of the Russian platinum-group metals complex and consolidation of a position at the world market of platinum-group metals (PGM). Russia possesses a high potential for resource growth and platinoid reserves, and technogenic waste of complex ore processing can become a considerable part of the process in the near future. All major producers of PGM in the world have technogenic objects of different importance, but the largest deposits of platinum metals relate to the Russian mining and metallurgical complex (Dodin \& Izoitko, 2006; Petrov, Greiver, \& Lazrenkov, 2001).

\section{Material Studied}

In Russia it is practical to take into account impounded mill tailings of sulphide copper-nickel ores, old pyrrhotine concentrates (OPC), impounded magnetite concentrates and slag-dust dumps of the mining and metallurgical company "Norilsk Nickel" (MMC NN), as well as technogenic platinum-metal chromite placer deposits of Ural and Aldan.

\subsection{Norilsk Technogenic Deposits}

At MMC NN considerable losses of platinum-group metals (up to 20\%) are connected with concentration of primary sulphide copper-nickel stock and depends on the type of ores and the technologies of separation. At concentrating rich ores in silicate tails whose yield is $16-20 \%$, remove only $3-4 \%$ MPG is only removed. When disseminated ores are concentrated, the loss of the platinum metals with tailing amounts to $20 \%$. The application of large-scale concentration schemes with a wide range of operations (gravitation, specific gravity preparation, floatation, etc.), which are mainly oriented at nonferrous metals concentration, large volume of recleaning operations and correspondingly the formation of significant amount of intermediate products containing PGM in various degree, leads to nonrecoverable technogenic leaking of noble metals.

In the metallurgical cycle of processing of copper and nickel concentrates of nonferrous metals the main part of platinum-group metals is collected at anode slimes of copper and nickel electrolysis. At MMC NN slime processing is realized according to the technologies providing the production of rich platinum metal concentrates 
which correspond to the refining requirements. The losses of PGM in the pyrometallurgical cycle are estimated at $3-5 \%$ and they are primarily connected with dump slags and dusts from melting and roasting process stages. It should be noted that a partial return of the formed intermediate products in the production work leads to some platinum-group metals circuiting in the technological cycle.

The oxidative pressure leaching poor pyrrhotine concentrates and subsequent flotation, the loss of MPG reaches the significant quantities $30-40 \% \mathrm{Pt}$ and $\mathrm{Pd}$, and $60 \%$ of the metals platinum satellites $(\mathrm{Rh}, \mathrm{Ru}, \mathrm{Ir}$ ) enters flotation tailings.

At MMC NN over 300 million tons of dry platinum-metal technogenic waste have been stored which present themselves a potential source of noble metals, especially taking into consideration that a share of high-grade ores in the mass of commodities from Norilsk deposits is decreasing and the volume of PGM produced domestically is decreasing as well (Dodin \& Izoitko, 2006; Kaitmazov \& Pykhtin, 2001).

Norilsk technogenic platinum-metal deposits were formed during several decades while processing high-grade sulphide copper-nickel ores. The formation of technogenic massifs of the Norilsk industrial region was going along with active geomechanical processes that determined the migration conditions of noble metals and their reallocation. The combination of these processes coupled with other natural and technology factors determine two trends in the formation of PGM technogenic deposits, viz. the migration of platinum-group metals in technogenic group products and their concentration that contribute to the occurrence of zones extremely rich in platinoids.

The storage of dump waste washed products and metallurgical production is characterized by low regularity of storage and mixture of different-type products (dumps of off-balance ores and overburden, tailings, slags, cinders, old pyrrhotine concentrates, bottom sediments of storage ponds, etc.), it especially developed at the first stage of the MMC NN operation while processing high-grade sulphide copper-nickel ores, and then pyrrhotine ores processing.

\subsubsection{Mill Tailings}

The PGM potential resources of old mill tailings exceed 800-1000 tons. The tailings storage of Norilsk concentrating mill №1 with an area of 6.2 square kilometers and total reserves of some 240 million tons of final tailings is the largest of the Norilsk technogenic deposits. The tailings storage material is presented by indiscrete mass containing from 0.2 to $5.5 \mathrm{~g} / \mathrm{t}$ PGM. On the whole the tailings contain the same combination of platinum minerals as in the initial copper-nickel ores. The impounded tailings are characterized by a higher content of platinum (up to $2.1 \mathrm{~g} / \mathrm{t}$ ), palladium (up to $5.8 \mathrm{~g} / \mathrm{t}$ ), rhodium (up to $0.24 \mathrm{~g} / \mathrm{t}$ ), iridium (up to $0.044 \mathrm{~g} / \mathrm{t}$ ), ruthenium and osmium (up to 0.01-0.05 g/t), gold (up to $1.4 \mathrm{~g} / \mathrm{t}$ ), copper (up to $0.8 \mathrm{~g} / \mathrm{t}$ ), nickel (up to $0.6 \mathrm{~g} / \mathrm{t}$ ).

Currently tails are partially involved in the processing in the batch for pyrometallurgical operations. However, much of MPG in the tails stockpiled is in the form of free minerals that makes it more appropriate selection of rich platinometallnyh concentrates using processing techniques thus reducing losses.

\subsubsection{Old Pyrrhotine Concentrates and Ferrous Cakes}

The ores of Talnakhsk and Oktyabrsk deposits are mainly presented by pentlandite-chalcopyrite-pyrrhotine variety which specific feature is a high content $(30-60 \%)$ of pyrrhotine $\mathrm{Fe}_{1-\mathrm{x}} \mathrm{S}$. The separate sulphide middlings, viz. nickel-pyrrhotine concentrate, is formed while flotation concentration of pyrrhotine ores. Due to a large yield and high content of PGM this concentrate represents a unique source of platinum metals production, and first of all rare platinoids, which occur only in the form of solid solutions in pyrrhotine and pentlandite.

$13-28 \% \mathrm{Ni} ; 4-6 \% \mathrm{Cu} ; 15-30 \% \mathrm{Co} ; 15-30 \%$ of PGM are extracted depending on nickel and pyrrhotine flotation mode (Naftal \& Shestakova, 2001). Chemical, mineralogical and grain-size compositions of nickel-pyrrhotine concentrate are determined by combination of the initial ores and concentration conditions. On average every ton of nickel is contained in 20-25 tons of iron and 12-17 tons of sulphur. In spite of substantial progress and efficiency of modern methods of autogenous smelting, the processing of such material for matte in Norilsk conditions was considered unprofitable until essential advance in PGM price. Nickel-pyrrhotine concentrate has been impounded in tailings storages for many years which today represent a serious contaminating factor: a solid part is inclined to dusting, and the presence of an artificial pond, where there is a material processed with a flotation agent, results in soil erosion, change of cryogenic environment and sewage pollution.

Old pyrrhotine concentrate (OPC) consists of extra fine particles (57-95\% of class $-0.045 \mathrm{~mm}$ ), that makes its processing much more difficult. It is made up of oxides of silicon, calcium, aluminium, magnesium (35-40\%), nonferrous metals sulfides $(3-6 \%)$ and iron in the form of magnetite $(10-15 \%)$ and pyrrhotine $(35-45 \%)$. OPC 
contains up to $10 \mathrm{~g} / \mathrm{t}$ and more of PGM, $0.3 \mathrm{~g} / \mathrm{t}$ of $\mathrm{Au}$, over $10 \mathrm{~g} / \mathrm{t}$ of $\mathrm{Ag}, 1-3 \%$ of Ni and $\mathrm{Cu}, 0.1 \%$ of $\mathrm{Co}$ (Kaitmazov \& Pykhtin, 2001; Makarov, 2010; Senyutina, 2006).

The total reserves in pyrrhotine tailings are estimated at 10 million tons, approximate potential resources of platinum and palladium in them exceed 100 tons, gold -3 tons, silver -100 tons, nickel and cobalt - over 500 thousand tons. The noble metals are dissipated in complex and fine composition of sulfide minerals in the form of impregnations that makes mechanical methods of their separation inefficient. Besides, a change of sulfide minerals properties during storage decreases the efficiency of conventional technologies application for sulfide minerals processing.

In GMK "NN" OPC processed by flotation, preceded by the classification and grinding in ball mills. Finished concentrate OPC is combined with the general nickel concentrate from the Norilsk processing plant .The disadvantage of this system is the total unification of nickel concentrate and increasing of the unit cost of energy in further pyrometallurgical processing of the material. Since 2009 the number of OPC $25-30 \%$ (mass) of pyrrhotite concentrate added to Talnakh dressing plant co-processing technology pressure oxidation leaching at the Nadezhda Metallurgical Plant. The disadvantage of this process is the essential loss of MPG during pressure oxidation leaching.

\subsubsection{Magnetite Concentrates}

Magnetite concentrate tailings are potential technogenic deposits of PGM, which had been formed by 1975 when processing high-grade chalcopyrite ores of Talnakhsk deposit. At that time ferroplatinum was not extracted from those ores and PGM content in final floatation tailings reached $26 \mathrm{~g} / \mathrm{t}$.

GMK "NN" is working off of the technogenic magnetite deposit formed in the processing of chalcopyrite-rich ore deposits of the Talnakh. The using of concetrates "Knelson" and concentration tables "Gemeni" produce concentrate gravity containing $5.7 \mathrm{~kg} / \mathrm{t}$ precious metals. During only one year 12,000 kg MPG about 1500 tonnes to 1000 tonnes of nickel copper were received from mignetitovyh concentrates.

\subsubsection{Slag-Dust Dumps of Pyrometallurgical Conversions}

The dump slags and dusts from dry and wet gas cleaning of metallurgical furnaces in the slag-dust dumps of MMC NN present a potential source of noble and nonferrous metals.

The dump slags and dusts from gas cleaning system collect some PGM during pyrometallurgical operations of copper-nickel ore processing. Dusts represent small-size metal shots, matte and metallic phase, which are formed as a result of melt frothing while bubbling and oxidation of sulfides. PGM are collected in the $\mathrm{Fe}-\mathrm{Cu}-\mathrm{Ni}$ metallic phase, metallic iridium and silver, newly-formed sulfides, selenides and tellurides of platinum-group metals, condensates of volatile compounds fumes-oxides of osmium, ruthenium, iridium and silver.

The dusts from the gas cleaning systems are characterized by a higher content of osmium, ruthenium and iridium compared to initial ores in which platinum and palladium prevail.

The resources of noble metals (gold +PGM) at the slag dump of Nickel plant are estimated at more than 20 tons. The content of metals in slag is extremely non-uniform; the variations differ from two-digit content of noble metals to less than ten per cent of $\mathrm{Cu}$ and $\mathrm{Ni}$.

On the whole, the level of noble metals content in the slag dumps (the total content of PGM and Au in different dumps varies from 1 to $2.2 \mathrm{~g} / \mathrm{t}$ ) and their resources allow speaking about metallurgical dump slag as a potential raw material which apart from noble metals contain: $\mathrm{Ni}-16$ thousand tons (content from 0.04 to $0.12 \%$ ), $\mathrm{Cu}-52$ thousand tons (content from 0.2 to $0.37 \%$ ) and $\mathrm{Co}-11$ thousand tons (content from 0.05 to $0.07 \%$ ). Considerable correlation of $\mathrm{Cu}, \mathrm{Ni}, \mathrm{Co}$ and noble metals can be observed in slag-dust samples, that makes it possible to assume the possibility of extraction of nonferrous metals, PGM, gold and silver by concentration methods.

\subsection{Urals Technogenic Deposits}

During two centuries of the Urals platinum placer deposits exploitation technogenic platinum metal and chromite placer deposits with rich reserved were formed mainly in two industrial hubs-Isovsky and Nizhne-Tagilsky ones (Dodin \& Izoitko, 2006; Petrov, Greiver, \& Lazrenkov, 2001). The microparticles of PGM minerals and gold with an average size of 2-12 micron with variations from 1-2 to 20-30 microns predominate in the technogenic Urals placer deposits, which are not extracted by standard gravitational method when primary placer deposits development. The valuable constituents of the Urals platinum placers are presented by over 30 types of PGM, free gold and silver, chromospinelides, magnetite, menaccanite. The main platinum group metal minerals of the placers are isoferroplatinum and tetraferroplatinum. There are dozens of PGM tons in the Urals 
technogenic placer deposits (mainly platinum, osmium and iridium), as well as tens of thousands tons of high-chromium platinum group metal chromospinelides and tons of associated gold.

\subsection{Siberian Technogenic Deposits}

It is also necessary to pay attention to technogenic reserves of platinum containing chromites formed when developing platinum placer deposits of Aldan (Inaglinsk and Kondersk deposits). Chromite concentrates extracted when placer concentration are related to a chemical type (content of $\mathrm{Cr}_{2} \mathrm{O}_{3}<48 \%, \mathrm{Cr}$ : $\mathrm{Fe}<3: 1$ ). Being a complex raw material chromites contain up to $0.5-1 \mathrm{~g} / \mathrm{t}$ of platinum metals which are mostly in scattered forms and they are difficult to be processed by concentration methods. Annual technogenic accumulation of chromites makes up to 50 thousand tons, therefore the problem of platinoid extraction is not less topical than the main component extraction, viz. chrome. Profitable chemical and metallurgical processing of placer technogenic deposits of chromites which are relatively small can be realized only while production of commercial chromic compounds (for example, high-priced chromic anhydride or metallic chrome) and associated platinum containing product when mining placers including mobile modular units, right after extraction of placer platinum concentrate in the concentration cycle (Petrov, 2001).

\section{Conclusion}

Summing up it can be noted that recent research shows that the objects of technogenic platinum containing raw material vary by their nature, metal content, scale of accumulation and commercial value. In spite of big volumes, secondary resources are characterized by unstable content of PGM and nonferrous metals. The forms of finding platinum group metals are so that raw material is difficult to be processed by conventional technological schemes. At that production cost of PGM extraction from technogenic deposits sometimes can be lower than when concentration of initial ores and sands, whereas the cost intensive operations connected with mining, crushing, grinding and classification are excluded from the processing chain.

The substantial factor that restraining the involvement of technogenic raw material in processing is the fact that they are considered by major mining enterprises, first of all as geotechnical systems providing long-term storage of mining waste, and in a less degree as secondary mineral resources. From this point of view concessionary development of technogenic platinum metal deposits with use of modern hydrometallurgical technologies is likely to be perspective.

\section{References}

Dodin, D. A., \& Izoitko, V. M. (2006). Ore Concentration, 6, 19-23.

Kaitmazov, N. G., \& Pykhtin, B. S. (2001). Nonferrous Metals, 6, 41-42.

Makarov, V. A. (2010). Noble metals of technogenic mineral objects of the Siberian region: resources and problems of geological-technological evaluation. II International congress Nonferrous metals of Siberia 2010. Krasnoyarsk. Collection of papers, 37-45.

Naftal, M. N., \& Shestakova, R. D. (2001). Nonferrous Metals, 6, 43-48.

Petrov, G. V. (2001). Concentration of platinum group metals when processing conventional and nonconventional platinum metal raw material. SPb. Saint-Petersburg Mining Institute, 106.

Petrov, G. V., Greiver, T. N., \& Lazrenkov, V. G. (2001). Modern state and technological prospects of platinum metal production when processing chromite ores. SPb: Nedra, 200.

Senyutina, A. B. (2006). Geology and Prospecting. 6, 70-73.

\section{Copyrights}

Copyright for this article is retained by the author(s), with first publication rights granted to the journal.

This is an open-access article distributed under the terms and conditions of the Creative Commons Attribution license (http://creativecommons.org/licenses/by/3.0/). 